\title{
Metabolism of urea in sheep
}

\author{
By M. R. COCIMANO* aNd R. A. LENG \\ Department of Biochemistry and Nutrition, \\ School of Rural Science, University of New England, \\ Armidale, NSW, Australia \\ (Received 9 August I966-Accepted I I October 1966)
}

I. The entry rates of urea into the urea pool of the body fluids have been measured in sheep given rations varying in crude protein percentage from 3.5 to 27.3 .

2. Results obtained with a single injection and with continuous infusions of $\left[{ }^{14} \mathrm{C}\right]$ urea were essentially the same.

3. The difference between the entry rate and the rate of excretion of urea in the urine was taken to indicate the quantity of urea degraded in the alimentary tract.

4. Plasma concentrations and urea entry rates were significantly and linearly related.

5. The relationship between excretion rate and plasma urea concentration was best described by a cubic equation.

6. Degradation of urea in sheep was found to be extensive in all the animals studied; as the protein intake increased, the quantity of urea degraded also increased but the percentage of urea entering the body pool that was degraded was decreased. Animals given a ration containing $3.5 \%$ crude protein degraded $76-92 \%$ of the urea entering the body pool.

7. A rectilinear relationship was found between pool size and plasma urea concentration. The urea space in animals given low-protein rations was significantly less than in animals on highprotein rations.

8. The effects of starvation for 2,4 and 6 days on urea metabolism in sheep were investigated. In all the sheep starved for 2 days there was a significant increase in urea pool size, but the entry rate was markedly depressed indicating a retention of urea in the body pool on starvation.

9. A significant amount of nitrogen was found to go through the system: rumen ammonia- $\rightarrow$ portal blood ammonia $\rightarrow$ blood urea $\rightarrow$ rumen ammonia.

I0. Urea excretion rate, urea clearance by the kidney, urine flow rate and the ratio of the concentration of urea in urine to that in plasma (urea $U: P$ ratio) were also examined.

11. There were significant correlations between urine flow rate and urea excretion and between plasma urea concentration and urine flow rate.

It is well established that endogenous urea enters the reticulum and rumen of sheep and cattle (for review see Phillipson, 1964) where it is hydrolysed to ammonia by bacterial urease and may be utilized by the micro-organisms in their nitrogen anabolism. Urea enters the rumen in the saliva (McDonald, I948; Houpt, 1959; Somers, I961 $a, b$ ) and by diffusion across the rumen wall (Simonnet, Le Bars \& Mollé, I957; Houpt, 1959; Juhász, 1965). Entry rate of urea into the rumen and its utilization by the microorganism must be of great importance to sheep and cattle feeding on low-protein diets (Schmidt-Nielsen, Schmidt-Nielsen, Houpt \& Jarnum, I957; Egan \& Moir, r965; Clark, 1965). However, there is little quantitative information and few studies have been made of the extent of hydrolysis of urea in the alimentary tract. Urea production rates in sheep have been investigated by Packett \& Groves (1965) using a method based on clearance of an injected urea load. A single injection of $\left[{ }^{14} \mathrm{C}\right]$ urea has been used to determine the rate of urea production and degradation in goats (Decker, Hill,

* Rockefeller Foundation Scholar. Present address: INTA, San Carlos de Bariloche, Argentina. 
Gärtner \& Hornicke, 1960; Gärtner, Decker \& Hill, 1961; Decker, Gärtner, Hornicke \& Hill, I96r). However, urea metabolism on low-protein diets has not been examined.

Under many pastoral conditions, sheep and cattle may exist for considerable periods on pastures containing $3 \%$ or less of crude protein.

In the investigations now reported the extent of recycling of urea nitrogen in sheep on diets of different protein content has been studied by radioisotope dilution techniques applied to the measurement of urea entry rates, particularly under conditions of low protein intake. A preliminary report of this work has been published elsewhere (Cocimano \& Leng, I966).

\section{EXPERIMENTAL}

\section{Animals and feeding regime}

Merino ewes were housed singly in pens. Each animal was fitted with a rumen cannula at least 12 weeks before the experimental period. Groups of between four and six animals were given one of the rations shown in Table I. Before the experiments all the animals had been on the ration for at least 12 weeks. For 7 days up to and including the day of the experiment, the sheep were given the daily ration in twelve equal amounts at hourly intervals over $12 \mathrm{~h}$ (from $07.00 \mathrm{~h}$ to $19.00 \mathrm{~h}$ ). This feeding regime was found to produce a constant level of urea in the blood between $12.00 \mathrm{~h}$ and $22.00 \mathrm{~h}$. Infusions or injections of $\left[{ }^{14} \mathrm{C}\right]$ urea were made on the 7 th day of each period. Between these periods the sheep were given the full ration once daily.

\section{Table I. Description of rations}

\begin{tabular}{|c|c|c|c|}
\hline $\begin{array}{c}\text { Ration } \\
\text { no. }\end{array}$ & Constituent & $\begin{array}{c}\text { Crude } \\
\text { protein } \\
(\%)\end{array}$ & $\begin{array}{l}\text { Nitrogen in- } \\
\text { take of sheep } \\
\text { (g/day) }\end{array}$ \\
\hline I & $450 \mathrm{~g}$ chopped wheaten straw $+50 \mathrm{~g}$ lucerne* & 3.5 & $2 \cdot 8$ \\
\hline 2 & $500 \mathrm{~g}$ chopped wheaten chaff & 4.5 & $3 \cdot 6$ \\
\hline 3 & $300 \mathrm{~g}$ lucerne $+300 \mathrm{~g}$ wheat grain & I 3.5 & $13 \cdot 0$ \\
\hline 4 & $500 \mathrm{~g}$ chopped lucerne & $17 \cdot 0$ & 13.6 \\
\hline 5 & $800 \mathrm{~g}$ chopped wheaten chaff $+200 \mathrm{~g}$ chopped lucerne & $9 \cdot 0$ & 14.4 \\
\hline 6 & $800 \mathrm{~g}$ lucerne & $17 \cdot 0$ & $21 \cdot 8$ \\
\hline 7 & $700 \mathrm{~g}$ lucerne $+\mathrm{r} 00 \mathrm{~g}$ casein & $27 \cdot 3$ & $35^{\circ} 0$ \\
\hline
\end{tabular}

* $+7 \mathrm{~g}$ of dicalcium phosphate, $+5 \mathrm{~g}$ of mineral-vitamin mix, $+\mathrm{s} \cdot 3 \mathrm{~g}$ of $\mathrm{NaCl}$. The mineral-vitamin

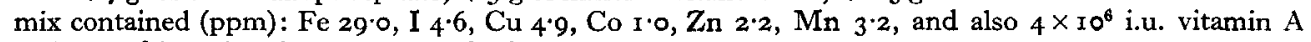
and $3 \times 10^{6}$ i.u. vitamin $D$ per ton of mix.

\section{Measurements of urea entry and excretion rates}

Animals were prepared with jugular vein and bladder catheters on the evening before an experiment. Entry rates of urea were determined from isotope dilution results either after a single injection or a continuous infusion of $\left[{ }^{14} \mathrm{C}\right]$ urea. $\left[{ }^{14} \mathrm{C}\right]$ urea was infused intravenously at a rate of $\mathrm{I} \mu$ mole $(0 \cdot 2, \mu \mathrm{c}) / \mathrm{min}$; no priming dose was given. In the single injection experiments approximately $40 \mu \mathrm{c}, 4 \mathrm{mg}$ of $\left[{ }^{14} \mathrm{C}\right]$ urea, were injected intravenously. In all the experiments blood samples were obtained at intervals up to $540 \mathrm{~min}$ after the injection or commencement of infusion. Usually samples were obtained at $15 \mathrm{~min}$ intervals from 360 to $540 \mathrm{~min}$ after the beginning of the experi- 
ment, but in the early studies samples were taken at $30 \mathrm{~min}$ intervals from $\circ$ to $540 \mathrm{~min}$. Urine samples from a catheter placed in the bladder were collected at 30 min intervals.

\section{Chemical methods}

Urea in plasma and urine, and ammonia in rumen fluid, were determined using the micro-diffusion technique of Conway \& O'Malley (1942). All estimations were made in duplicate and immediately after sampling.

\section{Isolation and assay of the specific radioactivity of plasma urea}

Blood samples (Io $\mathrm{ml}$ ) were obtained from a jugular vein catheter and placed in centrifuge tubes containing I drop of heparin $(3000$ units $/ \mathrm{ml})$ as anticoagulant. The tubes were immediately centrifuged at $1500 \mathrm{~g}$ for $5 \mathrm{~min}$ and the plasma was separated. Samples of plasma $(4 \mathrm{ml})$ plus $100 \mathrm{mg}$ urea as a carrier were transferred to $50 \mathrm{ml}$ centrifuge tubes and diluted with $8 \mathrm{ml}$ water and deproteinized by the successive addition of $4 \mathrm{ml} 0.5 \mathrm{~N}-\mathrm{Ba}(\mathrm{OH})_{2}$ and $4 \mathrm{ml} 7 \%$ (w/v) $\mathrm{ZnSO}_{4}$. After centrifugation at $\mathrm{r}_{5} 00 \mathrm{~g}$ for $5 \mathrm{~min}$ the supernatant liquid was filtered and freeze-dried overnight. The dried material was dissolved in $0.4 \mathrm{ml}$ water and the urea was crystallized by the addition of approximately 8-10 $\mathrm{ml}$ dioxan. The crystals were separated by filtration in Gooch crucibles, recrystallized twice from hot water with dioxan and finally filtered on to weighed Gooch crucibles and the weight of urea was determined. The crystals were dissolved in $4 \mathrm{ml}$ water and $0.5 \mathrm{ml}$ portions were counted in $\mathrm{Io} \mathrm{ml}$ of a scintillation mixture (Bray, 1960), with a Nuclear Chicago Scintillation System 725 (Nuclear Chicago Corp., Illinois, USA). The channels ratio method of Hendler (1964) was used to correct for quenching. Urea was determined in the remaining solution.

It was found that, during infusions of $\left[{ }^{14} \mathrm{C}\right]$ urea made over $18 \mathrm{~h}$, closely similar estimates of specific radioactivities of plasma urea were obtained when urea was isolated by the above procedure and when $0.5 \mathrm{ml}$ portions of the protein-free filtrate, containing a known quantity of urea, were counted without prior isolation of urea. This showed that there was a negligible incorporation of $\left[{ }^{14} \mathrm{C}\right]$ from labelled urea into circulating substrates. In all subsequent experiments the specific radioactivity of urea was determined by counting $0.5 \mathrm{ml}$ portions of deproteinized plasma, but usually the results were checked by isolating the urea from at least two samples per experiment.

\section{RESULTS}

In the tables the results are expressed as means with their standard errors (SE). When calculations have been made from the results of, say, the urea clearance, these values are expressed as the means with their ses of the individual estimates in each sheep. Since the expected value of the ratio $x / y$ is given approximately by

$$
E\left(\frac{x}{y}\right)=\frac{E(x)}{E(y)}-\frac{\text { covariance }(x, y)}{[E(y)]^{2}}+\frac{E(x)}{[E(y)]^{3}} \text { variance }(y)
$$

it can be seen that the values of urea clearance estimated in each animal and then averaged are not necessarily identical with the ratio of the means of urea excretion 
and plasma urea concentration on each ration. Similarly values for the $U: P$ ratio (see p. 364) estimated from means are not the same as values estimated from individual results. In these studies results were obtained for individual sheep and then averaged.

\section{Measurements of entry rates of urea using a continuous infusion of $\left[{ }^{14} \mathrm{C}\right]$ urea}

The change with time in the specific radioactivity of circulating urea during a constant infusion of $\left[{ }^{14} \mathrm{C}\right]$ urea into a sheep given ration 6 is shown in Fig. $\mathrm{I}$. The shape of the curve was typical of that found for sheep on the other rations.

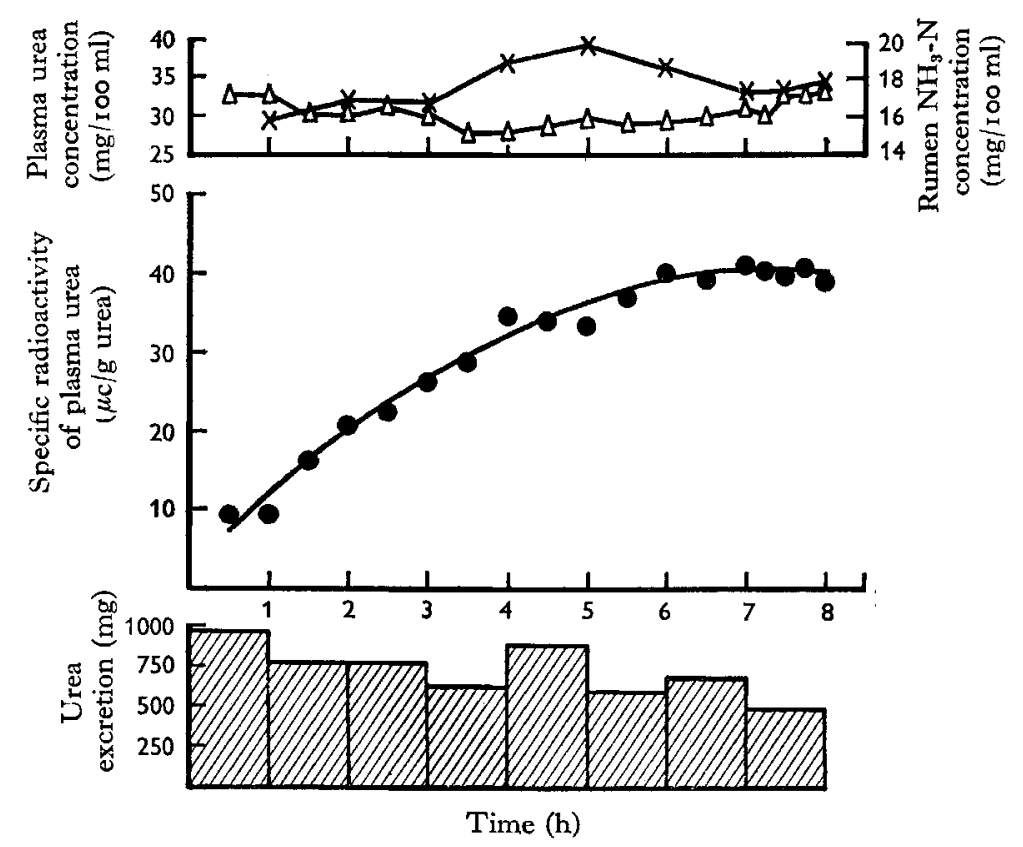

Fig. I. Specific radioactivity (SR) of plasma urea during a constant infusion of $\left[{ }^{14} \mathrm{C}\right]$ urea into a sheep given ration $\mathrm{I}$. (The plasma urea, rumen ammonia concentrations and the quantities of urea excreted over the experimental period are also shown.) $\left[{ }^{14} \mathrm{C}\right]$ urea was infused at a rate of $80 \mathrm{~m} \mu \mathrm{c} / \mathrm{min}$. SR plasma urea; $\triangle$, plasma urea concentration; $x$, rumen ammonia concentration; $\square$, excretion of urea.

The concentrations of urea in blood and of ammonia in rumen fluid are also shown. As can be seen from the histogram, the excretion rate of urea over the period of the infusion was relatively constant.

Entry rate of urea (in $\mathrm{mg} / \mathrm{min}$ ) was calculated by dividing the infusion rate of $\left[{ }^{14} \mathrm{C}\right]$ urea (in $\mathrm{m} \mu \mathrm{c} / \mathrm{min}$ ) by the mean specific radioactivity of plasma urea (in $\mathrm{m} \mu \mathrm{c} / \mathrm{mg}$ urea) between 6 and $9 \mathrm{~h}$ after the infusion began.

The mean entry rates of urea in sheep on the different rations determined by the constant infusion technique are shown in Table 2. The degradation rate of urea was determined as the difference between entry and excretion rates of urea in individual sheep. 


\section{Measurements of parameters of urea metabolism using a single injection of $\left[{ }^{14} \mathrm{C}\right]$ urea}

The single injection technique of isotope dilution yields information on turnover time, pool size and the space through which the urea is distributed in the animal. The constant infusion and single injection techniques have been compared as means of

Table 2. Entry and degradation rates of urea in sheep as measured by the constant infusion technique

(Mean values with their standard errors)

\begin{tabular}{|c|c|c|c|c|c|c|c|}
\hline $\begin{array}{c}\text { Ration* } \\
\text { no. }\end{array}$ & $\begin{array}{l}\text { No. of } \\
\text { expts }\end{array}$ & $\begin{array}{l}\text { Sheep wt } \\
\text { (kg) }\end{array}$ & $\begin{array}{l}\text { Plasma urea } \\
\text { concentration } \\
(\mathrm{mg} / \mathrm{ro0} \mathrm{ml})\end{array}$ & $\begin{array}{c}\text { Urea entry } \\
\text { rate } \\
(\mathrm{mg} / \mathrm{min})\end{array}$ & $\begin{array}{l}\text { Urea excre- } \\
\text { tion rate } \\
(\mathrm{mg} / \mathrm{min})\end{array}$ & $\begin{array}{l}\text { Urea de- } \\
\text { gradation rate } \\
(\mathrm{mg} / \mathrm{min})\end{array}$ & $\begin{array}{l}\text { Percentage } \\
\text { of urea } \\
\text { entering } \\
\text { body pool } \\
\text { and which } \\
\text { is degraded }\end{array}$ \\
\hline $\mathbf{I}$ & 3 & $27 \cdot 7 \pm 1 \cdot 0$ & $5.6 \pm 0.7$ & $2 \cdot 5 \pm 0 \cdot 23$ & $0.2 \pm 0.09$ & $2 \cdot 3 \pm 0.10$ & 92 \\
\hline 2 & 4 & $30 \cdot 4 \pm I \cdot 2$ & $12 \cdot 0 \pm 0.8$ & $7.3 \pm 0.60$ & $1 \cdot 0 \pm 0.07$ & $6 \cdot 3 \pm 0.61$ & 86 \\
\hline 4 & 3 & $34.8 \pm x \cdot 0$ & $36 \cdot 2 \pm 2 \cdot 7$ & $17 \cdot 9 \pm 1 \cdot 29$ & $7 \cdot 4 \dagger$ & $9.4 T$ & 56 \\
\hline 5 & 4 & $29 \cdot 8 \pm 0.7$ & $16 \cdot 6 \pm 3 \cdot 3$ & $10.0 \pm 0.50$ & $5 \cdot 6 \pm 2 \cdot 27$ & $4^{\circ} 4 \pm x \cdot 70$ & 48 \\
\hline 6 & 6 & $35^{\circ} 0 \pm 0 \cdot 6$ & $42 \cdot 5 \pm 1 \cdot 4$ & $28 \cdot 1 \pm I \cdot 28$ & $17 \cdot 7 \pm 1 \cdot 23$ & $10 \cdot 4 \pm I \cdot 25$ & 40 \\
\hline 7 & 4 & $34^{\prime} 1 \pm \mathrm{I} \cdot 0$ & $72 \cdot 6 \pm 2 \cdot 5$ & $37 \cdot 4 \pm 4 \cdot 88$ & $25 \cdot 2 \pm 2.03$ & $12 \cdot 2 \pm 3.56$ & 30 \\
\hline
\end{tabular}

* Details of the rations are given in Table 1 .

$\uparrow$ Only one result.

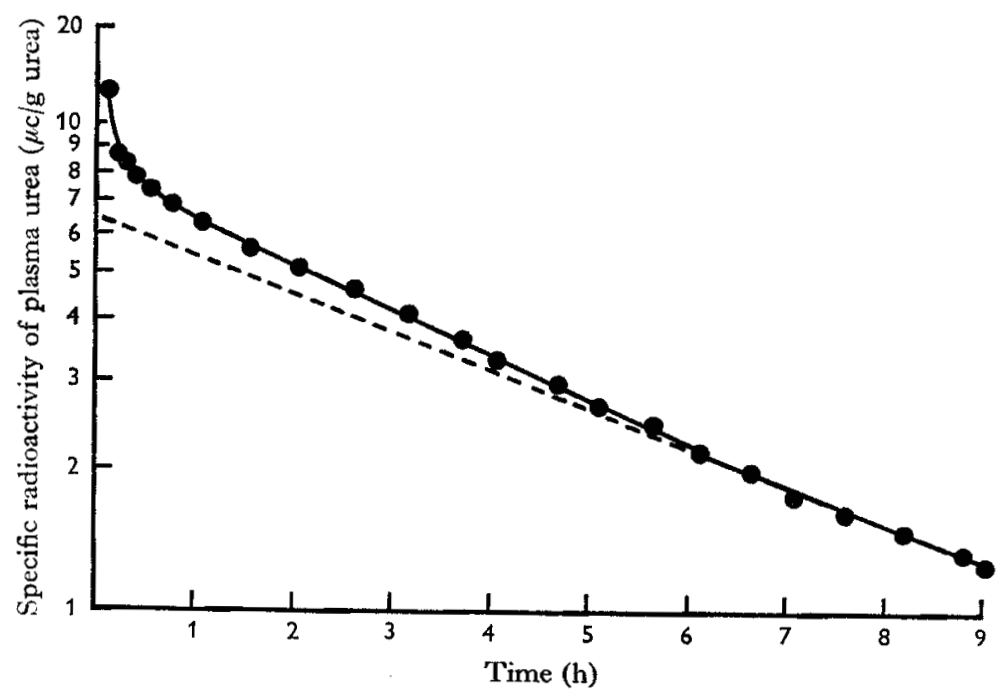

Fig. 2. Specific radioactivity (SR) of plasma urea after an injection of $\left[{ }^{14} \mathrm{C}\right]$ urea into six sheep given ration 3 . (53 $\mu \mathrm{c}$ of $\left[{ }^{14} \mathrm{C}\right]$ urea were injected.) $O, \log \mathrm{SR}$ plasma urea. The broken line indicates the extrapolated part of the curve used for estimating the specific radioactivity at zero time (i.e. $S R_{0}$ ).

measuring the entry rate of urea in sheep on different rations (Tables 2 and 3 ). Usually the parameters of urea metabolism were measured by the two techniques in the same sheep, but at intervals of about I week between the experiments. In other respects the 


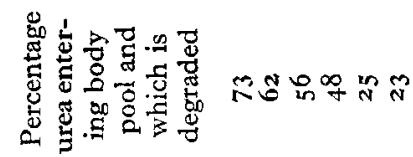

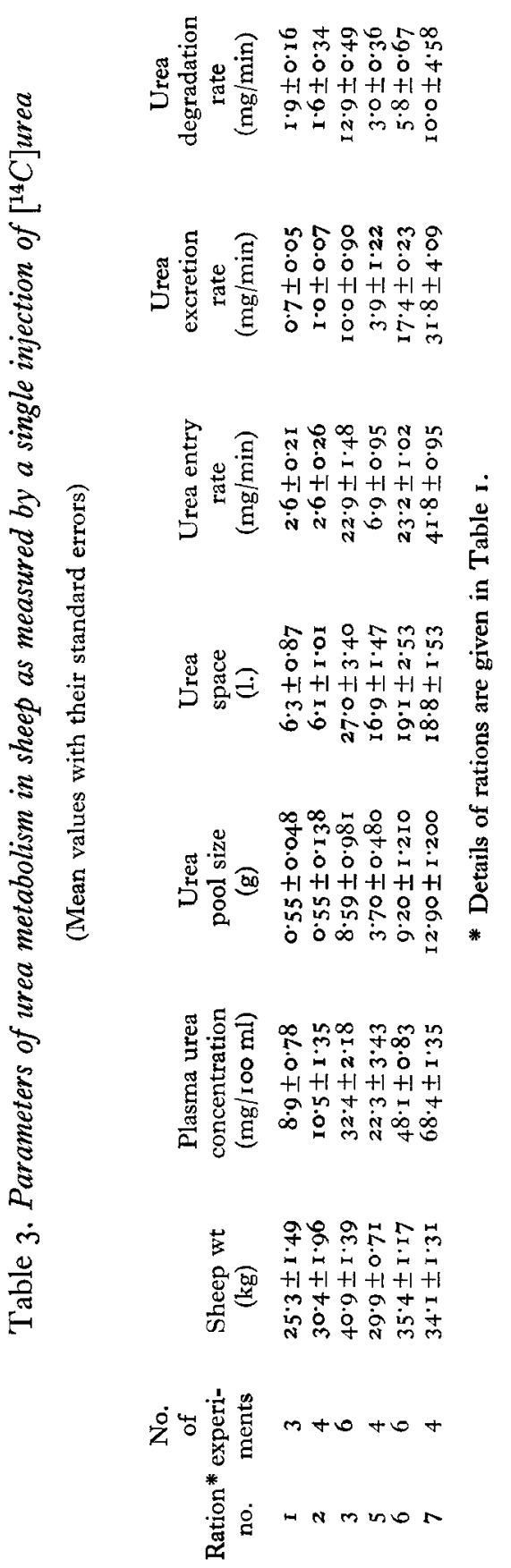


treatment of the animals was the same. A graph of log specific radioactivity against time after injection of $\left[{ }^{14} \mathrm{C}\right]$ urea for six sheep given ration 3 is shown in Fig. 2. The injection of $\left.{ }^{14} \mathrm{C}\right]$ urea (approximately $50 \mu \mathrm{c}, 4 \mathrm{mg}$ ) was made when the concentration of urea in the plasma was approximately constant and the condition of the animal was apparently in a fairly steady state (that is after the first four feeds were given) (Leng \& Leonard, 1965 ).

If the initial mixing period is ignored the following calculations can be made from single injection experiments (for review see Zilversmit, 1960). Extrapolation of the rectilinear part of the curve to zero time gives an estimate of the dilution of radioactivity at the time of injection if mixing has been instantaneous (i.e. specific radioactivity of plasma urea at zero time, $S R_{0}$ ). Urea pool size and urea space can be calculated as follows:

$$
\begin{gathered}
P_{s}(\mathrm{~g})=\frac{\text { injected dose }(\mu \mathrm{c})}{S R_{0}(\mu \mathrm{c} / \mathrm{g} \text { urea })}, \\
S(\mathrm{l} .)=\frac{\text { injected dose }(\mu \mathrm{c})}{S R_{0} \times \text { urea concentration }(\mathrm{g} / \mathrm{l} .)^{\circ}} .
\end{gathered}
$$

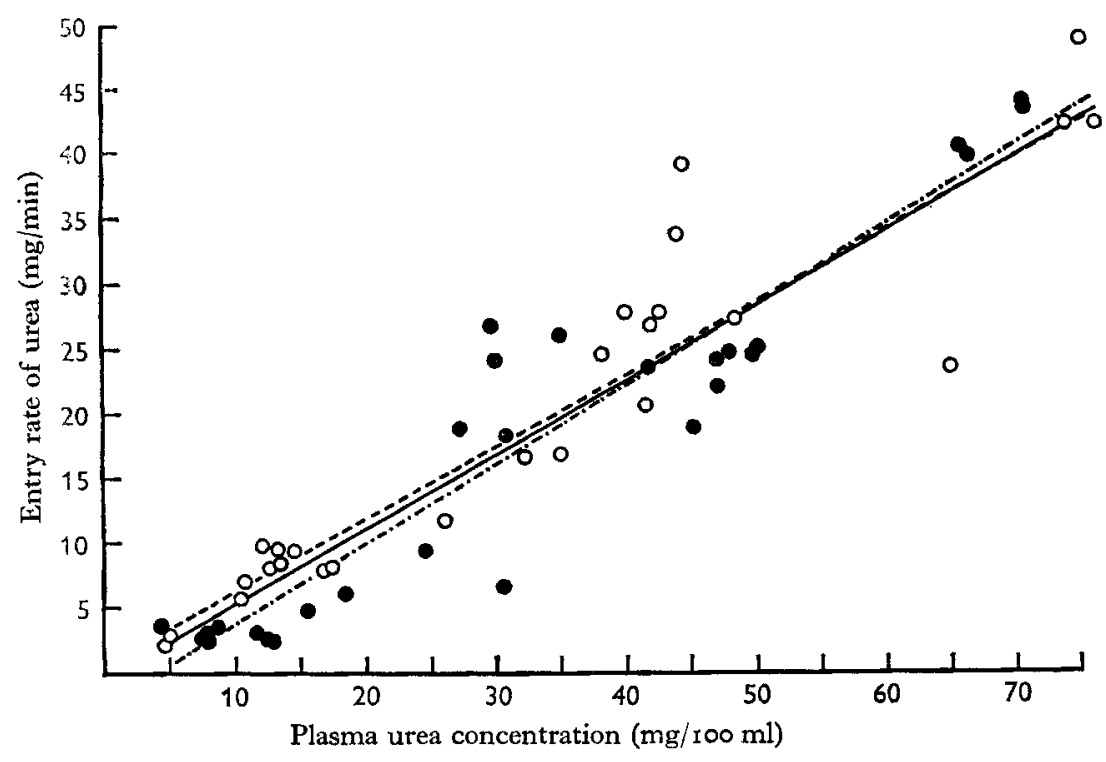

Fig. 3. Relationship between plasma concentration and entry rate of urea in sheep. $O$, results obtained with continuous infusion of $\left[{ }^{14} \mathrm{C}\right]$ urea; 9 , results obtained with a single injection of urea. The solid line indicates the line of best fit for all the results. The broken lines indicate the lines of best fit for the individual sets of values.

The half time $\left(t_{\frac{1}{2}}\right)$ is the time for half the radioactivity to be lost from the urea pool and can be calculated directly (see Fig. 2).

The entry rate $(E)$ is calculated using the following equation:

$$
E=\frac{P}{t_{\frac{1}{2}} \times \mathrm{I} \cdot 44} \text { (see Zilversmit, rg60). }
$$

The results obtained by the single injection technique are shown in Table 3 . 
Although there were significant differences between entry rates of urea measured by the two techniques in the same animals, there were also differences between days in the plasma urea concentrations.

Plasma concentrations of urea $X$ (in $\mathrm{mg} / \mathrm{I00} \mathrm{ml}$ ) and urea entry rates $E$ (in $\mathrm{mg} / \mathrm{min}$ ) were linearly related and described by the equations:

$$
E=0.772+0.556 X \text {, residual standard deviation }(\mathrm{RSD})=4.9 \mathrm{mg} / \mathrm{min}( \pm 0.043)
$$

for results obtained with the constant infusion technique, and

$$
E=-2.53 \mathrm{I}+0.620 X, \mathrm{RSD}=5.6 \mathrm{mg} / \mathrm{min}( \pm 0.054)
$$

for results obtained with the single injection method (Fig. 3).

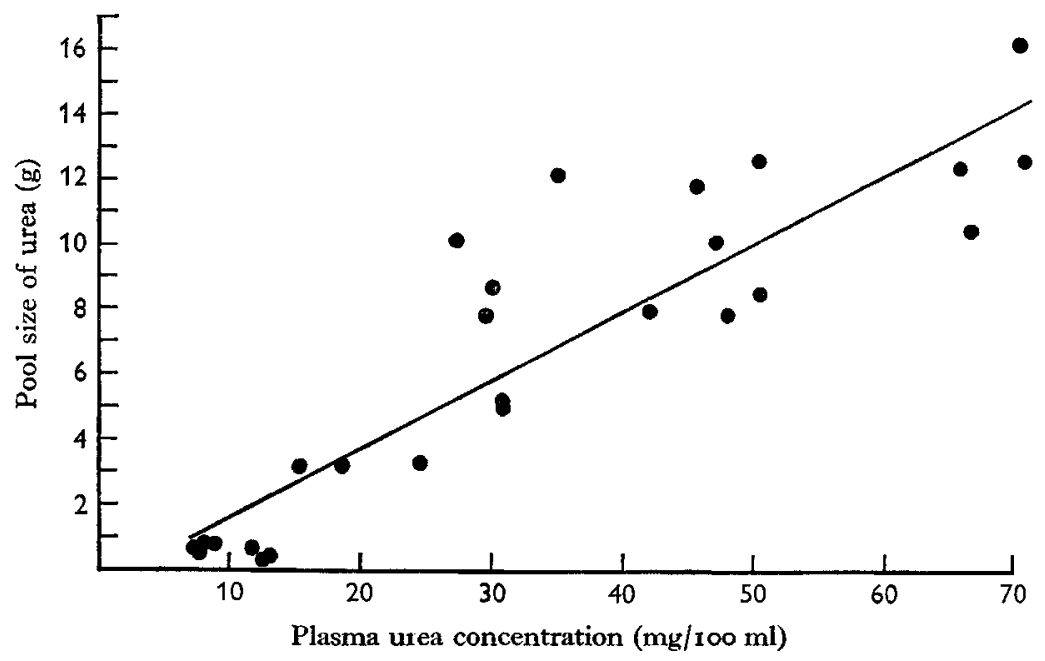

Fig. 4. Relationship between plasma concentration and pool size of urea in sheep.

An analysis of covariance indicated that the results obtained using the different techniques were homogeneous, since there were no significant differences between intercepts or between slopes of the regression lines.

The line of best fit of the combined results was

$$
E=0.668+0.582 X, \quad \operatorname{RSD}=5.3 \mathrm{mg} / \mathrm{min}( \pm 0.034) \text { (Fig. } 3 \text { ). }
$$

Urea pool size $P$ (in g) was also significantly related $(P<0.0 \mathrm{I})$ to the plasma concentration of urea $(X)$ (Fig. 4). The regression equation of the relationship was

$$
P=-0.484+0.208 X, \quad \operatorname{RSD}=2.35 \mathrm{~g}( \pm 0.023) \text {. }
$$

\section{Urea excretion rates on different rations}

The mean excretion rates of urea in sheep on the various rations are shown in Tables 2 and 3 . The relationship of excretion rate $E_{n}$ (in $\mathrm{mg} / \mathrm{min}$ ) and plasma concentration of urea $(X)$ (Fig. 5) was best described by the equation:

$$
\begin{aligned}
E_{n} & =2.114-0.356 X+0.026 X^{2}+0.00022 X^{3} ; \\
\operatorname{RSD} & =3.534 \mathrm{mg} / \mathrm{min}( \pm 0.313)( \pm 0.0009)( \pm 0.00008) .
\end{aligned}
$$




\section{Effect of starvation on parameters of urea metabolism}

Measurements of urea entry rate in four animals given ration 6 have been made in fed animals and in animals starved for 2, 4 and 6 days. The results are shown in Table 4 . Plasma urea concentrations and urea pool size were significantly greater after 2 days of starvation than in fed animals $(P<0.01)$, although urea entry rates and excretion rates were significantly lower $(P<0.01)$.

In starvation the ratio of the concentration of urea in urine to that in plasma (i.e. urea $U: P$ ratio) fell significantly and there was a marked fall in urea clearance, particularly after 2 days of starvation.

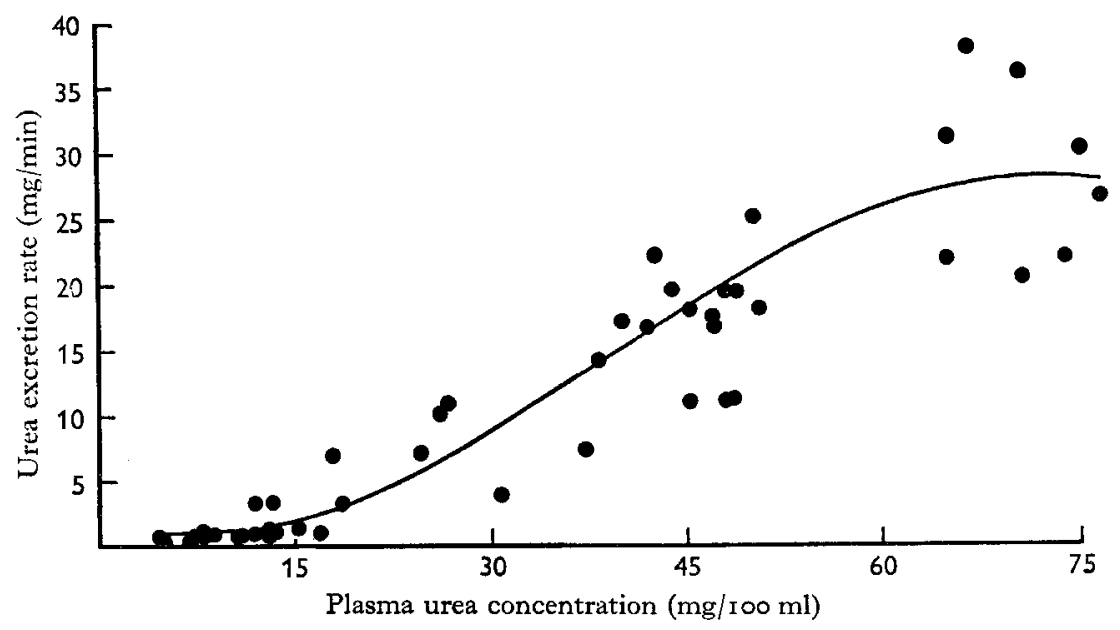

Fig. 5. Relationship between plasma concentration and the urine excretion rate of urea in sheep.

Urine flow rate was also found to fall after 2 days of starvation, but was approximately equal to that in fed animals on the 4 th and 6th days of starvation (Table 4).

The results of starvation on entry rate and plasma concentrations of urea can be seen in Fig. 6.

\section{Cycling of urea and ammonia nitrogen}

The entry rates of urea measured in these experiments include all the urea that enters the body pool. Urea may be produced in the liver from ammonia arising in the alimentary tract, from deamination of amino acids and from ammonia arising from nitrogenous bases. Urea produced in the liver that enters the rumen or intestinal tract will be converted into ammonia and may be reabsorbed to be reconverted into urea in the liver. Thus in sheep there may be extensive cycling of urea and ammonia nitrogen, and attempts have been made to measure the extent of this recycling.

Sheep were infused for $9 \mathrm{~h}$ with $\left[{ }^{14} \mathrm{C}\right]$ urea and then a load of urea was included in the infusate so that the animals were receiving $6.4 \mathrm{mg} / \mathrm{min}$ for a further $9 \mathrm{~h}$. The difference between the sum of the entry rate before loading $\left({ }^{U} B\right)$ and the rate of infusion of the urea load $(I)$ and the urea entry rate after loading $\left({ }^{U} A\right)$ should indicate the extent of recycling of the infused urea $(R)$, i.e. $R={ }^{U} A-\left({ }^{U} B+I\right)$, provided the 


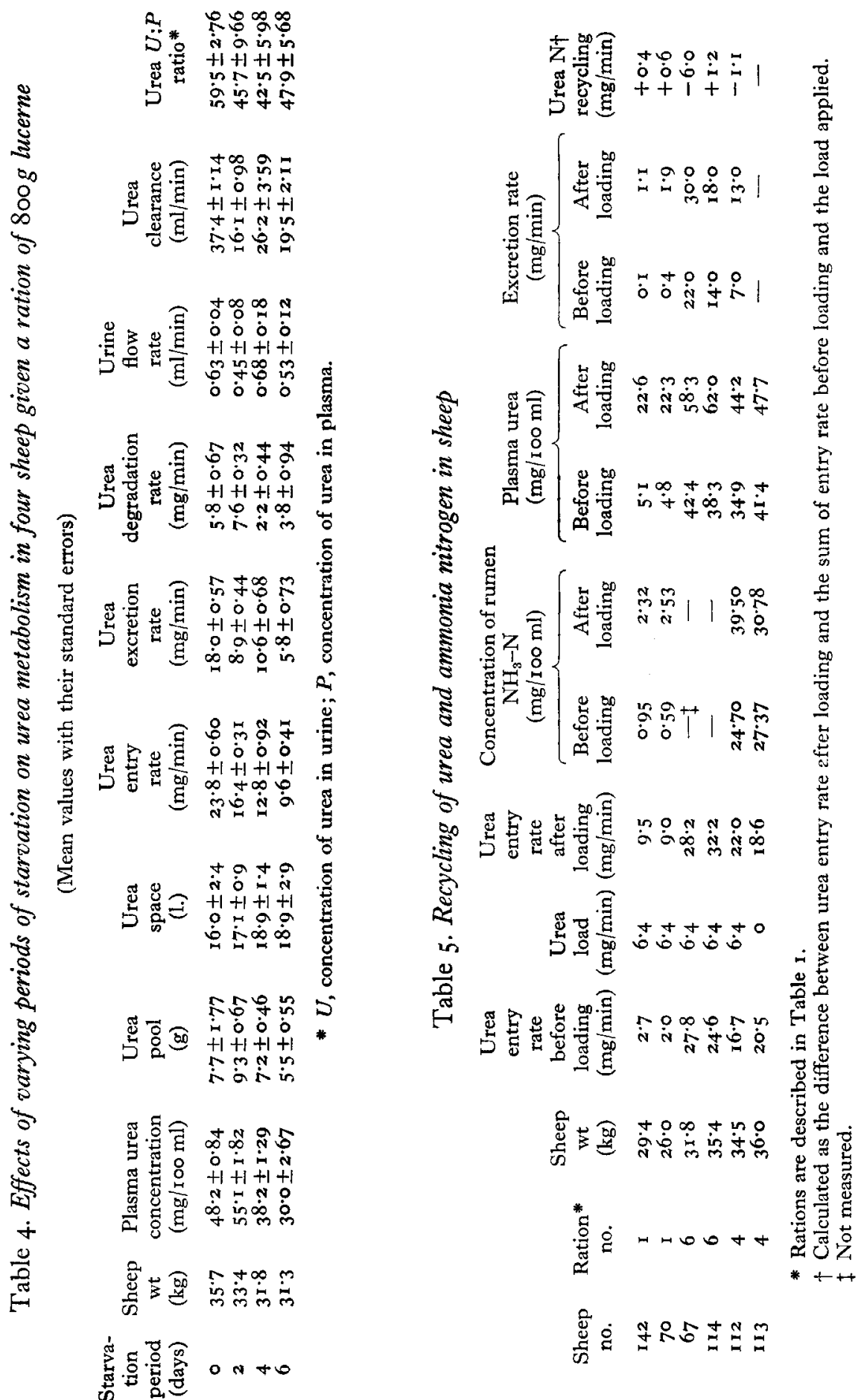


entry rate of endogenous urea did not change over the period of the experiment and that the infusion of urea had no effect on endogenous urea production and degradation.

Mean results for two sheep given ration $\mathrm{I}$ are shown in Fig. 7. In some experiments

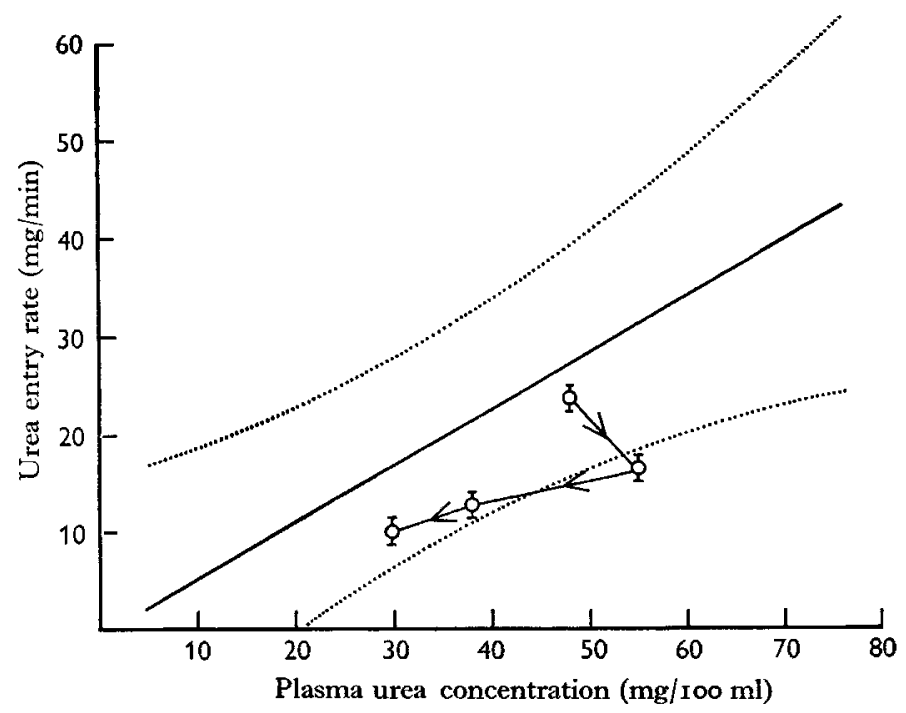

Fig. 6. Effects of varying periods of starvation on the entry rate of urea and its plasma concentrations in four sheep given ration 6 . The relationship between plasma urea concentration and urea entry rates, with its $95 \%$ confidence limits, is shown as unbroken and broken lines respectively. The circles indicate urea entry rates. The mean entry rates are joined by arrows indicating in order the results in animals starved $0,2,4$ and 6 days.

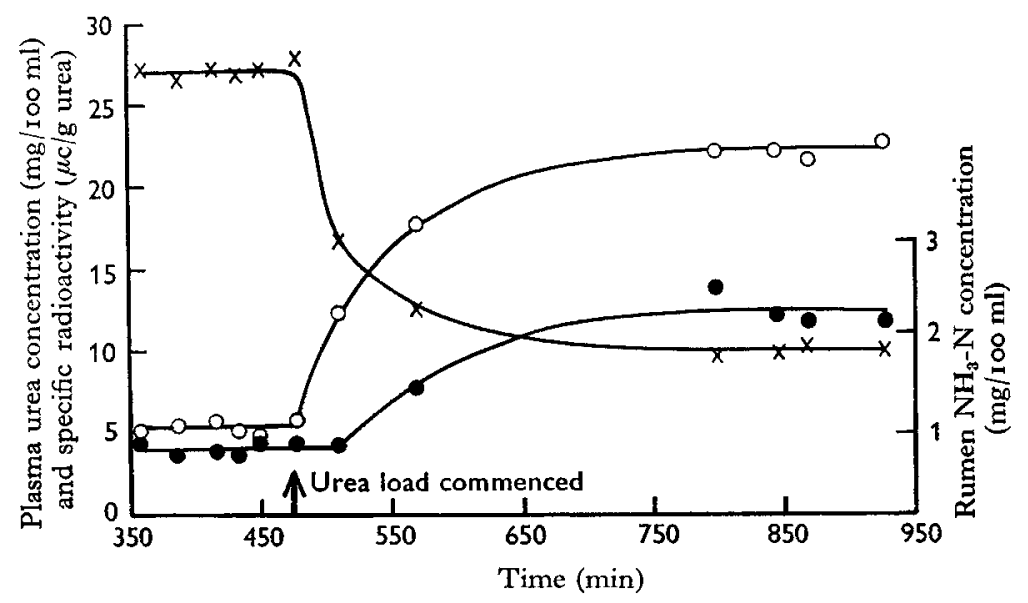

Fig. 7. Effects of infusion of urea $(6.4 \mathrm{mg} / \mathrm{min})$ on plasma urea concentration, urea specific radioactivity and ammonia concentration in the rumen of sheep. $\left(\left[{ }^{14} \mathrm{C}\right]\right.$ urea was infused at a rate of $6 \mathrm{r} \cdot 7 \mathrm{~m} \mu \mathrm{c} / \mathrm{min}$.) $O$, plasma urea concentration; $\times$, specific radioactivity of urea; $\bullet$, rumen ammonia concentration.

plasma urea and rumen ammonia concentrations and excretion rate of urea in urine were studied (Table 5).

It was found that only the animals given the wheaten straw ration (ration 1 ) could 


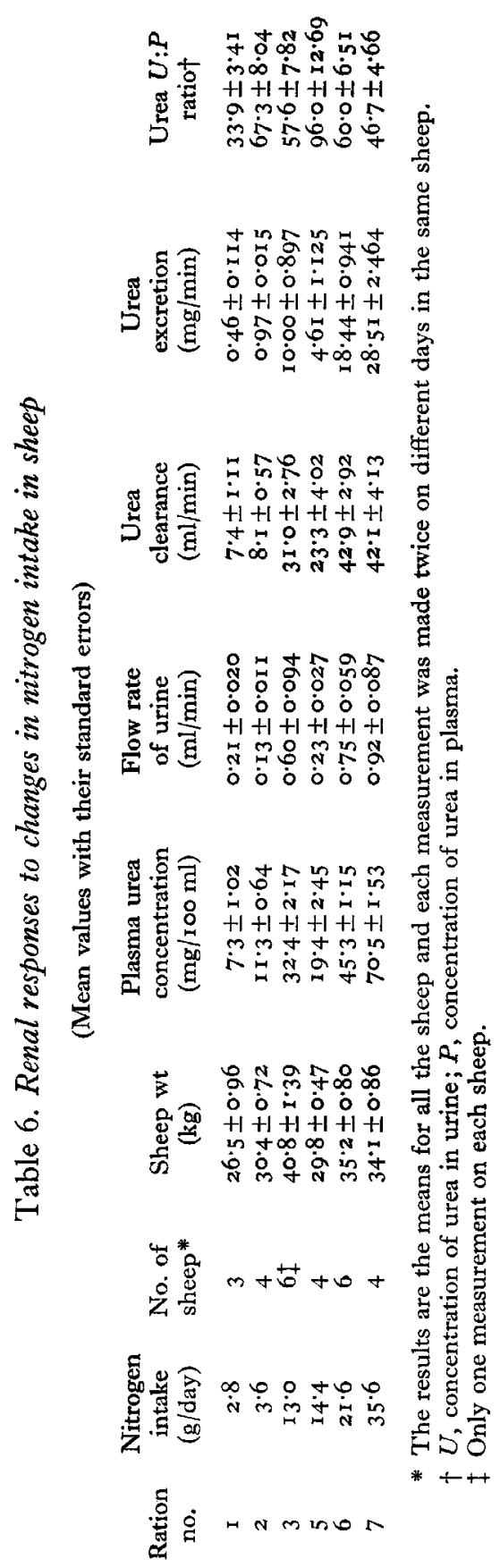


be induced to eat over the full $\mathrm{I} 8 \mathrm{~h}$ of the experiment and therefore the results for other animals were confounded with a changing endogenous urea entry rate as indicated by sheep I I3, given ration 6, which was not loaded with urea (Table 5). Sheep 67 did not consume a proportion of its ration over the second $9 \mathrm{~h}$ period.

In sheep given the lowest protein ration the amount of nitrogen recycled from the intestinal tract as ammonia was apparently $8 \%$ of the urea $\mathrm{N}$ infused.

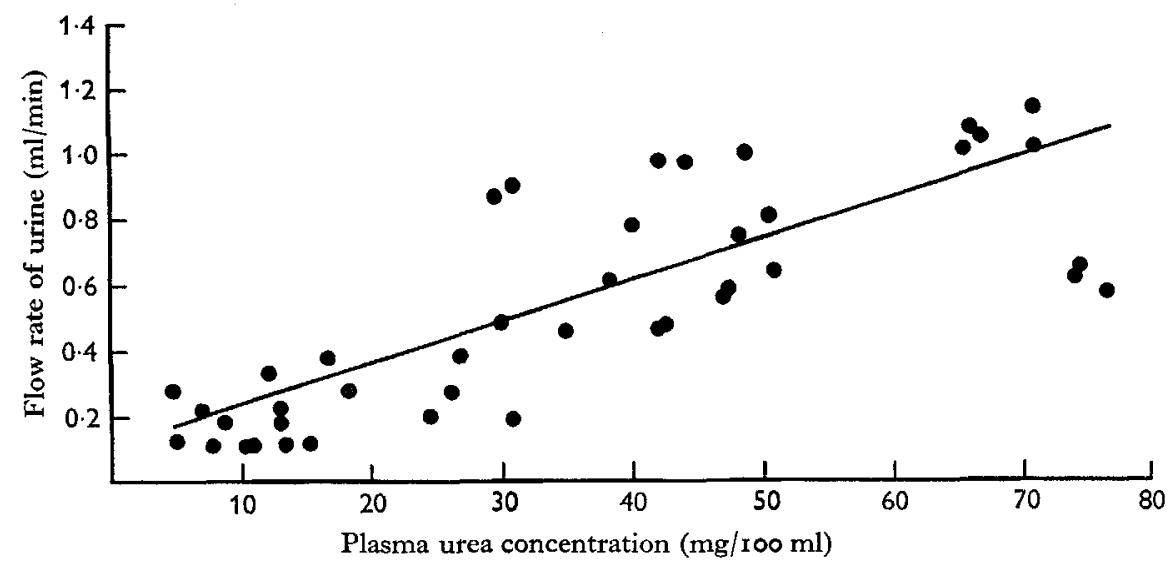

Fig. 8. Relationship between concentration of urea in plasma and urine flow rate in sheep.

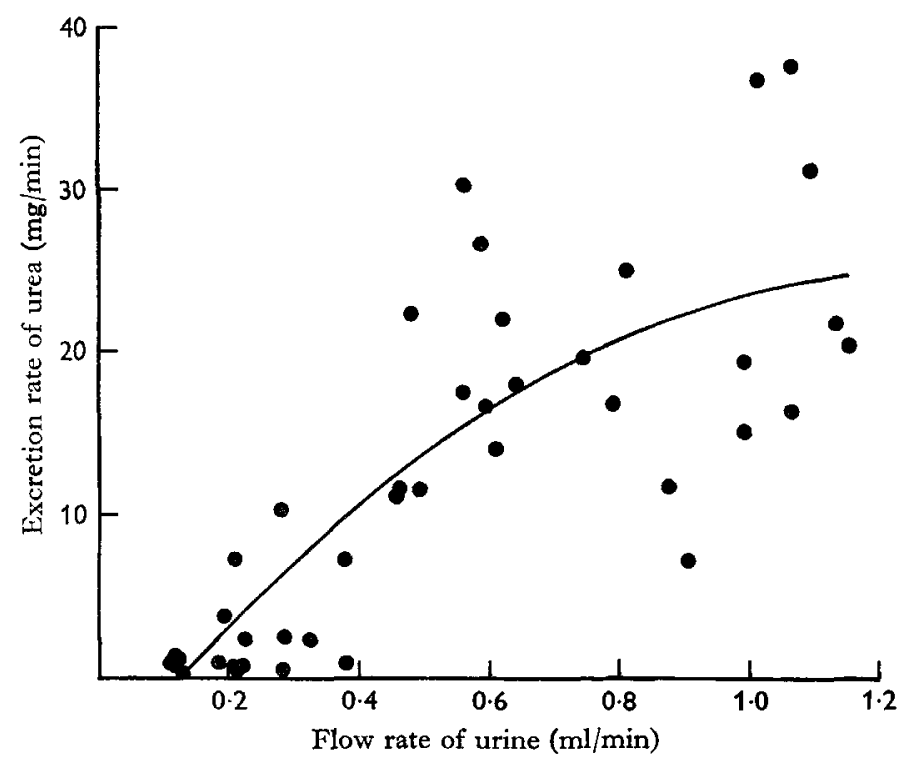

Fig. 9. Relationship between urine flow rate and urea excretion in sheep.

Effects of nitrogen intakes on urea excretion in sheep

Urine flow rate and urea clearance in sheep given the various rations are shown in Table 6; both were found to increase with the plasma concentration of urea. However, the urea $U: P$ ratios were variable. 


\section{Relationship between plasma urea concentration, urine flow rate and urea excretion rate}

There was a significant $(P<0.01)$ rectilinear relationship between the urine flow rate $U_{f}$ (in $\mathrm{ml} / \mathrm{min}$ ) and the concentration of urea in plasma $(\mathrm{mg} / \mathrm{100 \textrm {ml }})(X)$. The regression equation was

$$
\left.U_{f}=0.1 \mathrm{I} 4+0.01_{3} X ; \mathrm{RSD}=0.262 \mathrm{ml} / \mathrm{min} \text { (see Fig. } 8\right)( \pm 0.002)
$$

Urea excretion $E_{n}$ (in $\mathrm{mg} / \mathrm{min}$ ) and urine flow rate $U_{f}$ (in $\mathrm{ml} / \mathrm{min}$ ) were also significantly $(P<0.05)$ correlated. The line of best fit was described by the quadratic equation

$E_{n}=6 \cdot 04+48 \cdot 98 U_{f}-19 \cdot 35 U_{f}^{2} ; \operatorname{RSD}=6 \cdot 26 \mathrm{mg} / \mathrm{min}(\mathrm{see}$ Fig. 9$)( \pm 11 \cdot 56)( \pm 9 \cdot 60)$.

\section{DISCUSSION}

The hydrolysis of urea in the alimentary tract of animals has been demonstrated in many species including man (Walser \& Bodenlos, I959), pig (Liu, Hays, Svec, Catron, Ashton \& Speer, 1955), rat (Chao \& Tarver, I953), mouse (Leifer, Roth \& Hempelmann, I948), rabbit (Houpt, I963; Regoeczi, Irons, Koj \& McFarlane, I965) and domestic ruminants (Houpt, 1959; Decker et al. I960). However, the nutritional significance of the urea returned to the alimentary tract is not fully known. In ruminants any urea nitrogen entering the localities of bacterial fermentation (i.e. rumen, caecum and large intestine) can be used by micro-organisms for growth. The protein synthesized in the rumen becomes available to the animal by digestion lower down the intestinal tract. In animals which are coprophagic, such as the rabbit, the ingestion of faecal pellets causes any bacterial protein synthesized from urea in the large intestine or caecum to come under normal digestive processes (Houpt, 1963) and in this way amino acids synthesized in the lower intestine may become available to the animal.

Grazing ruminants may at times have access only to roughage of $3-4 \%$ crude protein content, particularly in areas with mainly graminaceous pastures and a pronounced alternation of wet and dry seasons, as in wide areas of Australia and Africa, and also where animals are being fed for survival as in drought conditions. Animals survive under these conditions for considerable periods, suggesting that they conserve their nitrogen in some way. The early work of Read (1925) first demonstrated net urea retention by animals when it was shown that there was practically no urea in the urine of pregnant camels on a low-protein diet. These findings were later confirmed by the work of Schmidt-Nielsen et al. (1957).

That urea nitrogen is returned to the rumen of sheep was first indicated by the work of McDonald (I948). Since these investigations there has been considerable work aimed at demonstrating that the urea produced in the ruminant is not completely excreted (Houpt, I959; Decker et al. I960; Packett \& Groves, 1965; Clark, I965). It is well known that urea enters the rumen in the saliva (McDonald, I948; Somers, 1961 $a$ ) and also by diffusion across the rumen wall (Houpt, 1959; Juhász, 
1965; Decker et al. I960), but the quantities of urea entering the alimentary tract are still not fully known, particularly in animals on low-protein diets. In the experiments reported here, quantitative information is presented which clearly shows that there is a retention of nitrogen in sheep on low-protein rations, and that these animals may utilize a considerable proportion of the urea produced in the body.

Regression analysis of results obtained with either a single injection or a continuous infusion of $\left[{ }^{14} \mathrm{C}\right]$ urea showed that essentially similar relationships between the entry rate and plasma concentration of urea were obtained with the two techniques.

Examination of the relationship of $\log$ specific radioactivity with time after a single injection of $\left[{ }^{44} \mathrm{C}\right]$ urea suggests that in animals on the higher-protein rations there is a rapidly equilibrating compartment (probably the extracellular fluid) and that there is then a slow equilibration of urea with a large compartment which corresponds with the remainder of the body water (Fig. 2). The mixing time of $\left[{ }^{14} \mathrm{C}\right]$ urea with the body pool was apparently close to the mixing time of tritiated water with the body water (Till \& Downes, I962) and mixing was apparently only complete after about 5-6 h (Fig. 2). Over the initial period after the injection, the specific radioactivity of urea in circulating blood was higher than that in the surrounding tissue fluids. During this time the specific radioactivity of the urea entering the alimentary tract and being excreted in the urine was higher than the average throughout the body. It would be expected therefore that the entry rate as measured would be an overestimate of true entry rate since the specific radioactivity at zero time would be an underestimate. However, in contrast to expectations, the urea entry rate was usually slightly less at low concentrations of plasma urea when measured by using a single injection rather than a constant infusion of $\left[{ }^{14} \mathrm{C}\right]$ urea (Fig. 3 ). Small experimental errors in determination of specific radioactivities between 6 and $9 \mathrm{~h}$ after the injection would probably result in quite large errors in the extrapolation value at zero time. Thus it is believed that the continuous infusion technique probably gives more nearly true values for entry rates of urea.

In constant infusion and single injection experiments using radioactive isotopes aimed at measuring entry rates of compounds such as glucose for example, recycling of ${ }^{14} \mathrm{C}$ from other compounds may cause considerable error (Steele, I964). It is probable that with $\left[{ }^{14} \mathrm{C}\right]$ urea there is very little recycling of ${ }^{14} \mathrm{C}$ from non-urea compounds back into urea, since the ${ }^{14} \mathrm{CO}_{2}$ produced from urea is diluted by a large body pool of carbon dioxide.

There was a significant correlation between entry rate and plasma concentration of urea indicating that a fairly accurate estimate may be made of the entry rate of urea in a fed sheep from its plasma concentration (Fig. 3).

Urea excretion on the experimental rations varied with the protein intake. However, only $10-25 \%$ of the urea produced in sheep on the low-protein ration $(3-4 \%$ crude protein) was lost in the urine, but this percentage increased as protein intake increased (Tables 2 and 3 ). Although a much greater proportion of the urea produced in the body was degraded by the animals on a low protein intake the quantities of urea degraded in the alimentary tract were much greater on the high-protein rations. It is not known how much of the urea hydrolysed in the alimentary tract is degraded in the rumen. The relationship between urea excretion and plasma concentration of urea is 
shown in Fig. 5. The curve appears to be sigmoidal, illustrating that at low protein intakes, and therefore low plasma urea concentrations (where the curve is well defined), there was an unavoidable loss of urea and that the concentrating ability of the kidney at high-protein intakes, or high plasma urea concentrations, may have reached a maximum. The few results at high plasma urea concentrations make it difficult, however, to place much emphasis on this part of the curve. Preston, Schnakenberg \& Pfander $\left(\mathrm{I}^{6} 65\right)$ and Somers $(\mathrm{I} 96 \mathrm{I} b)$ have shown that there is a significant correlation between plasma urea concentration and nitrogen intake.

With sheep on a poor-quality ration, Houpt (1959) estimated that the total urea nitrogen transfer into the alimentary tract was approximately $7 \cdot 8-\mathrm{r} 3^{\circ} \circ \mu \mathrm{moles} / \mathrm{h}$. In experiments in which the rumen was emptied and filled with artificial saliva, $5.2 \mathrm{~m}$-moles urea $\mathrm{N} / \mathrm{h}$ were transported into the rumen, and of this approximately $6 \%$ was entering in the saliva (Houpt, 1959). In the experiments now reported the degradation rate of urea varied from $2 \cdot 2 \mathrm{~m}$-moles/h in sheep on low-protein rations to $\mathrm{I} 2.8 \mathrm{~m}-\mathrm{moles} / \mathrm{h}$ on the highest protein intake. In animals ingesting $2.8 \mathrm{~g} \mathrm{~N} /$ day the net return of nitrogen as urea to the alimentary tract was $\mathrm{r} \cdot 6 \mathrm{~g}$ and therefore the nitrogen entering the rumen may have been as much as $4.4 \mathrm{~g} /$ day. On the ration with the greatest protein content the animal was consuming $35 \mathrm{~g} \mathrm{~N} /$ day and $5.6 \mathrm{~g}$ of nitrogen as urea was returned to the alimentary tract. The actual amount of urea degradation in the various parts of the gastro-intestinal tract is not at present known, but degradation may be high in sites other than the rumen.

The pool size of urea was correlated with plasma concentration and the urea space was approximately equal to the body water space except for animals on low-protein rations where the urea space was apparently considerably less. The volume of distribution of urea in animals given low-protein rations (i.e. rations I and 2) was between 20 and $25 \%$ of the body-weight. This observation has been repeated in other studies at present in progress (J. N. Nolan \& R. A. Leng, unpublished). It seems unlikely that the low space values are an artifact of the technique since errors due to utilization of urea before mixing is complete, which is possibly the major drawback of the single injection technique, would tend to cause an overestimate of urea pool size and space. A space equivalent to $20-25 \%$ of the body-weight approximates to that of the extracellular fluid of sheep and may indicate restriction of urea in the extracellular fluid. This phenomenon is being studied further.

The mixing time of injected urea in animals given high-protein rations was found to be approximately $6 \mathrm{~h}$, which would be expected if urea was distributed through the body water. In the studies of Packett \& Groves (1965) intravenously injected urea was believed to equilibrate with the body pool in sheep after $\mathrm{I}-2 \mathrm{~h}$. If urea is distributed throughout the body water, equilibration within this time is highly unlikely, since injected tritiated water takes up to $6 \mathrm{~h}$ to mix completely with the body water (Till \& Downes, 1962).

The retention of urea in the body pool on starvation has been shown previously (Packett \& Groves, 1965). Apparently in short-term starvation a mechanism operates that reduces excretion of urea and maintains a high plasma concentration and the quantity of urea in the body pool is maintained or even increased. Some of the retained 
urea nitrogen may be used by the ruminal organisms when the animal again eats, and this mechanism may assure the ruminal organisms of a readily available source of soluble nitrogen.

Recycling of urea through alimentary $\mathrm{NH}_{3} \rightarrow$ blood $\mathrm{NH}_{3} \rightarrow$ blood urea $\rightarrow$ alimentary $\mathrm{NH}_{3}$ must cause an overestimation of the net production rate of urea since the ammonia being reconverted into urea is included in the measurement. The nitrogen cycled through this mechansim may be of considerable importance to the ruminal organisms in that it probably assists in maintaining a relatively high ammonia concentration in the rumen, which may be necessary for cellulose digestion. Attempts were made to assess this recycling by infusing a load of urea and at the same time maintaining a constant infusion of $\left[{ }^{14} \mathrm{C}\right]$ urea, thus determining the entry rate of urea before and after loading (Table 5 and Fig. 7). Only with animals given low-protein rations (ration $\mathrm{I}$ ) was it possible to have the animals feeding at hourly intervals over the $\mathrm{I} 8 \mathrm{~h}$ of the infusion, and the results for the animals on other rations were confounded by a declining endogenous entry rate of urea over the second period when the urea load was administered. In two sheep on the low-protein ration, of an infusion of $6.4 \mathrm{mg}$ urea $/ \mathrm{min}, 0.5 \mathrm{mg} / \mathrm{min}$ apparently entered the alimentary tract, was reabsorbed as ammonia and converted again into urea. That is approximately $8 \%$ of the infused urea nitrogen entering the body was being repeatedly transferred between the blood and the fluid of the alimentary tract.

Since $73-92 \%$ of the urea entering the body pool is degraded in the alimentary tract, apparently a large proportion of this is converted into compounds more complex than ammonia. This may indicate the extent of the utilization of this nitrogen source by the micro-organisms of the intestinal tract of the sheep.

The high plasma concentration of urea after loading the animal with urea indicated that large quantities of urea were stored in the body pool of the sheep. If the space of urea in the body is unchanged by an infusion of urea (see Table 3 ) then, of $3 \cdot 26 \mathrm{~g}$ of urea infused over $9 \mathrm{~h}, \mathrm{I} \cdot \mathrm{I} O \mathrm{~g}$ were stored in the body pool and $0.68 \mathrm{~g}$ was excreted. Thus $\mathrm{I} \cdot 48 \mathrm{~g}$ of urea were degraded in the gastro-intestinal tract with $0.26 \mathrm{~g}$ of this being absorbed as $\mathrm{NH}_{4}{ }^{+}$and reconverted into urea.

The renal responses associated with changes in nitrogen intake by sheep may be confounded to some extent, since nitrogen intake was not the only variable in the diets and the dry-matter intake of the animals varied considerably between groups of sheep.

That the ration can affect entry and excretion rates is shown by the animals on ration 5 (i.e. $800 \mathrm{~g}$ chopped wheaten chaff plus $200 \mathrm{~g}$ chopped lucerne) which were given a ration with a low-nitrogen percentage but whose intake of crude protein was relatively high. In these animals entry rate was considerably less and the amount excreted, expressed as a percentage of the amount that entered, was also less than in animals on a similar protein intake, indicating that utilization of endogenous urea in these animals was relatively high and that repeated transfer of urea nitrogen between the alimentary tract and the plasma was probably low.

Unlike the results of Schmidt-Nielsen and co-workers with sheep and camels (Schmidt-Nielsen \& Osaki, 1958; Schmidt-Nielsen et al. 1957), the urea $U: P$ ratio did not approximate to the osmolar urea $U: P$ ratio (i.e. $U: P=5$ ). On nitrogen intakes of 
$2.8 \mathrm{~g} /$ day the urea $U: P$ ratio was 34 . This high ratio relative to that found by SchmidtNielsen \& Osaki ( $\left.195^{8}\right)$ is not readily explained. However, there was considerable difference in the diets given to the sheep in the two sets of experiments. In the investigations presented here a roughage ration was used, whereas Schmidt-Nielsen \& Osaki $\left(195^{8}\right)$ used a molasses, wheaten-straw diet which provided a readily fermentable carbohydrate source. That factors other than nitrogen intake may affect urea $U: P$ ratios was shown by Schmidt-Nielsen \& Osaki (1958). Two lambs on a haymolasses diet $(2 \cdot 3 \%$ protein) had urea $U: P$ ratios of $10-20$; when the diet was changed to raw cellulose-molasses (virtually no protein) the urea $U: P$ ratio did not change, but when $2 \mathrm{lb}$ grain were also given in one feed to the lambs there was an immediate drop in urea $U: P$ ratios to between 3 and 6 . This suggests that urea $U: P$ ratios may be affected by the type of ration given to the sheep. Clark $\left(1_{96} 6_{5}\right)$ has found a high urea $U: P$ ratio in sheep given low-protein rations. In the experiments now reported, the urea $U: P$ ratio was not as variable as in those of Schmidt-Nielsen $e$ al al. (1957) when urea $U: P$ ratios were found to vary between 5 and $25^{\circ}$.

Urea excretion was apparently associated closely with plasma urea concentration and also to a large extent with the flow rate of urine (Figs. 8, 9). The relationship between urine flow rate and urea excretion rate suggests that the rate of excretion of urea may be governed to a large extent by the flow rate of urine. However, there may be more reason to suppose that urine flow rate in sheep was governed by urea excretion at high-protein intakes since the concentration of urea in urine was of the order of $0.5 \mathrm{M}$ on these rations, whereas at low protein intakes the concentration was approximately 0.05 M. However, many other variables which may have a marked effect on urine flow rate were not measured.

We are indebted to the Australian Wool Research Committee, the University of New England and the Rockefeller Foundation for financial support for this project. The skilled technical assistance of Mr D. B. Brett and Mr J. Wilcher is also gratefully acknowledged.

\section{REFERENCES}

Bray, G. A. (1 960). Analyt. Biochem. 1, 279.

Chao, F. C. \& Tatver, H. (1953). Proc. Soc. exp. Biol. Med. 84, 406.

Clark, R. (1965). Yl S. Afr. vet. med. Ass. 36, 75 .

Cocimano, M. R. \& Leng, R. A. (1966). Proc. Aust. Soc. Anim. Prod. 6, 378.

Conway, E. J. \& O'Malley, E. (1942). Biochem. F. 36, 655.

Decker, P., Hill, H., Gärtner, K. \& Hornicke, H. (r960). Dt. tierärztl. Wschr. 67, 539 .

Decker, P, Gärtner, K., Hornicke, H. \& Hill, H. (1961). Pflügers Arch. ges. Physiol. 274, $28 \mathrm{~g}$.

Egan, A. R. \& Moir, R. J. (1965). Aust. F. agric. Res. 16, 437.

Gärtner, K., Decker, P. \& Hill, H. (1961). Pflügers Arch. ges. Physiol. 274, 281.

Hendler, R. W. (1964). Analyt. Biochem. 7, I 10.

Houpt, T. R. (1959). Am. F. Physiol. r97, I I 5.

Houpt, T. R. (1963). Am. F. Physiol. 205, I 144.

Juhász, B. (1965). Acta vet. hung. 15, 25.

Leifer, E., Roth, L. J. \& Hempelmann, L. H. (1948). Science, N. Y. ro8, 748.

Leng, R. A. \& Leonard, G. J. (1965). Br. F. Nutr. 19, 469.

Liu, C. H., Hays, V. W., Svec, H. J., Catron, D. V., Ashton, G. C. \& Speer, V. C. (I 955). F. Nutr. 57, 241.

McDonald, I. W. (1948). Biochem. F. 42, 584 .

Packett, E. V. \& Groves, T. D. D. (1965). F. Anim. Sci. 24, 34x. 
Phillipson, A. T. (Ig64). In Mammalian Protein Metabolism. Vol. 1, p. 7I. [H. B. Munro and J. B. Allison, editors.] New York: Academic Press Inc.

Preston, R. L., Schnakenberg, D. D. \& Pfander, W. H. (I965). F. Nutr. 86, 28 r.

Read, B. E. (1925). 7. biol. Chem. 64,615.

Regoeczi, E., Irons, L., Koj, A. \& McFarlane, A. S. (I965). Biochem. 7. 95, 521.

Schmidt-Nielsen, B. \& Osaki, H. (1958). Am. F. Physiol. I93, 657.

Schmidt-Nielsen, B., Schmidt-Nielsen, K., Houpt, T. R. \& Jarnum, S. A. (1957). Am. F. Physiol. 188, 477.

Simonnet, H., Le Bars, H. \& Mollé, J. (r957). C.r. hebd. Séanc. Acad. Sci., Paris 244, 943.

Somers, M. ( г6 г a). Aust. F. exp. Biol. med. Sci. 39, I I I.

Somers, M. (196і b). Aust. F. exp. Biol. med. Sci. 39, 123.

Steele, R. (1964). Fedn Proc. Fedn Am. Socs exp. Biol. 23, 671.

Till, A. R. \& Downes, A. M. (1962). Aust. F. agric. Res. 13, 335.

Walser, M. \& Bodenlos, L. J. (1959). F. clin. Invest. 38, I6I 7.

Zilversmit, D. B. (r960). Am. F. Med. 29, 832 . 